Tropical Journal of Pharmaceutical Research February 2021; 20 (2): 337-343

ISSN: $1596-5996$ (print); 1596-9827 (electronic) (C) Pharmacotherapy Group, Faculty of Pharmacy, University of Benin, Benin City, 300001 Nigeria.

\title{
Molecular docking study on columbin isolated from Tinospora cordifolia as a cholinesterase inhibitor
}

\author{
Joel O Onoja ${ }^{1,2}$, Taiwo O Elufioye ${ }^{1}$, Zaid A Sherwani ${ }^{3}$, Zaheer UI-Haq ${ }^{3}$ \\ ${ }^{1}$ Department of Pharmacognosy, Faculty of Pharmacy, University of Ibadan, Ibadan, ${ }^{2}$ Department of Pharmacognosy and \\ Environmental Medicine, Faculty of Pharmaceutical Sciences, University of Nigeria, Nsukka, Nigeria, ${ }^{3}$ Dr Panjwani Center for \\ Molecular Medicine and Drug Research, University of Karachi, Karachi-75270, Pakistan
}

*For correspondence: Email: toonitaiwo@yahoo.com; Tel: +234 8033850773

Sent for review: 9 August 2020

Revised accepted: 19 January 2021

\begin{abstract}
Purpose: To investigate the acetylcholinesterase (AChE) inhibitory potential of columbin and also to assess its binding affinity against AChE protein.

Methods: Crystals of columbin were isolated from the ethyl acetate fraction of Tinospora cordifolia using column chromatography and its structure was determined using x-ray crystallography. Ellman colorimetric assay was used to determine the AChE inhibitory effect in vitro while molecular docking was performed using the MOE 2015.010 software. The selected protein data bank (PDB) was modeled using PDB ID: 10CE (pacific electric ray).

Results: The crystal and structure refinement data of columbin were: $\mathrm{C}_{20} \mathrm{H}_{22} \mathrm{O}_{6}$, Orthorhombic, $P 2{ }_{12}{ }_{12}{ }_{1}$, $a=7.4951(2) \AA\left(\alpha=90^{\circ}\right), b=11.6451(3) \AA\left(\beta=90^{\circ}\right), c=19.5882(5) \AA\left(\gamma=90^{\circ}\right), V=1709.68(8) \AA^{3}, Z=$ 4 , Density (calculated) $=1.392 \mathrm{Mg} / \mathrm{m}^{3}$, absorption coefficient $=0.851 \mathrm{~mm}^{-1}$, goodness-of-fit on $F^{2}=1.091$, $T=100(2) \mathrm{K}$. Columbin demonstrated good AChE inhibitory effect with half-maximal inhibitory concentration (IC50) of $1.2993 \pm 0.17 \mathrm{mg} / \mathrm{mL}$. Molecular docking data revealed that it exhibited hydrophobic and hydrogen bonding interactions with the surrounding residues, and this accelerated complexation between the ligands and the active site of the enzyme.

Conclusion: Columbin may be useful in the management of neurodegenerative conditions such as Alzheimer's disease.
\end{abstract}

Keywords: Tinospora cordifolia, Columbin, Acetylcholinesterase, Single crystal diffraction, Molecular docking

\begin{abstract}
This is an Open Access article that uses a fund-ing model which does not charge readers or their institutions for access and distributed under the terms of the Creative Commons Attribution License (http://creativecommons.org/licenses/by/4.0) and the Budapest Open Access Initiative (http://www.budapestopenaccessinitiative.org/read), which permit unrestricted use, distribution, and reproduction in any medium, provided the original work is properly credited.
\end{abstract}

Tropical Journal of Pharmaceutical Research is indexed by Science Citation Index (SciSearch), Scopus, International Pharmaceutical Abstract, Chemical Abstracts, Embase, Index Copernicus, EBSCO, African Index Medicus, JournalSeek, Journal Citation Reports/Science Edition, Directory of Open Access Journals (DOAJ), African Journal Online, Bioline International, Open-J-Gate and Pharmacy Abstracts

\section{INTRODUCTION}

Molecular docking, a method that helps predict or anticipate the favored orientations of drug candidates (ligands) against macromolecular targets (protein) to make stable complex, has found remarkable importance in drug design and discovery. This field of drug design and discovery using computer aided simulations has witnessed several achievements in recent years, especially towards discovery of new drug leads [1].

Neurodegenerative disease refers to conditions resulting from prolonged collapse and deterioration of the nervous system, especially the nerve cells in the brain. [2]. Alzheimer's 
disease (AD) is a neurodegenerative condition that results in progressive loss of structure and function of neurons, ultimately leading to cognitive decline and deterioration [3]. Acetylcholine (ACh), which plays an important role in learning and memory processes, was the first neurotransmitter defect discovered in $A D$ [4]. In patients with $A D$, there is a drastic decrease in the production and half-life of $\mathrm{ACh}$ due to the presence of the enzymes acetylcholinesterase (AChE) and butyrylcholinesterase (BuChE) which catalyzes the breakdown of ACh [5].

Acetylcholine is a serine protease (EC 3.1.1.7) with binding site consisting of many domains [6] (Figure 1). The anionic domain is responsible for the cation $-\pi$ interactions with the protonated head of ACh while the acyl pocket dictates its selective binding capacity. The oxyanion hole, consisting of one molecule of water, facilitates the binding between enzyme and substrate through hydrogen-bond and also stabilizes the substrate tetrahedral transition state. The peripheral anionic site (PAS) moderates catalysis [7].

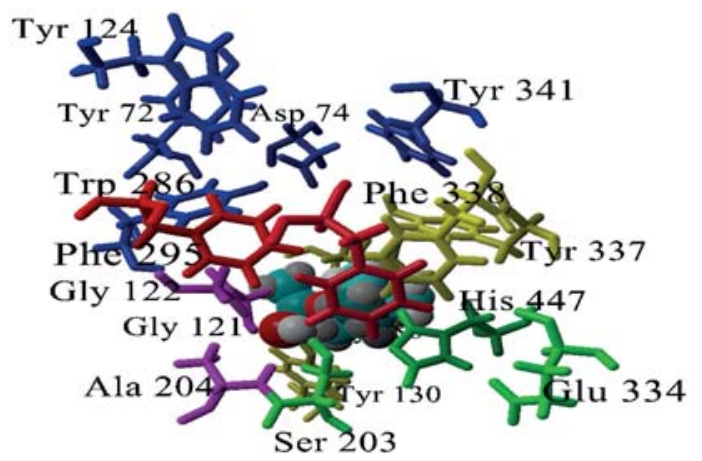

Figure 1: Domains of the binding site of human AChE: showing catalytic domain, (green) anionic domain (red), acyl pocket (purple) oxyanion hole (blue), peripheral anionic site (balls)

Tactics to improve cholinergic function in $A D$ have included stimulation of cholinergic receptors or increasing the half-life of acetylcholine released into the neuronal synaptic cleft by use of agents which restore the level of acetylcholine through inhibition of acetylcholinesterase and butyrylcholinesterase [8]. It has been shown that the inhibition of acetylcholinesterase holds a key role not only in boosting cholinergic transmission in the brain but also in decreasing aggregation of $\beta$-amyloid plaques and formation of neurofibrillary tangles in AD [9]. Consequently, AChE inhibitors are considered effective in the treatment of AD. Tinospora cordifolia is a shrub that belongs to the family Menispermaceae. This plant has several pharmacological effects such as antiallergic, bactericidal, osteoprotective, antioxidant, genoprotective antiinflammatory, uricosuric, antimalarial, antiperiodic, antispasmodic, antistress, hepatoprotective, antiviral, diuretic, febrifuge and immuno-stimulant [10-12]. The stem and root of the plant contains alkaloids like tembetarine, choline, magnoflorine, berberine, tinosporin, isocolumbin, palmetine, jatrorrhizine, aporphine, and tetrahydropalmatine which had anti-cancer, anti-diabetes, anti-viral, anti-inflammatory, anti-psychiatric and immunomodulatory actions [13]. Furthermore, the whole plant of $T$. cordifolia contains furanolactone, diterpenoid lactones, cleodrane derivatives columbin, tinosporides, tinosporin and jateorine which exerts vasorelaxant, antiinflammatory, anti-microbial, antihypertensive and anti-viral effects [14]. The present study was aimed at determining the crystal data and structure refinement of columbin isolated from $T$. cordifolia and assessing its binding affinity against acetylcholinesterase protein.

\section{EXPERIMENTAL}

\section{Plant collection, extraction and purification}

The stem of $T$. cordifolia collected from Enugu State, Nigeria was authenticated at Forest Research Institute of Nigeria with voucher number $\mathrm{FHI}$ 112287. Oven dried $\left(40^{\circ} \mathrm{C}\right)$ and powdered stem bark was extracted with methanol and the extract was further partitioned into hexane, dichloromethane, ethyl acetate and methanol. The ethyl acetate fraction was purified using column chromatography on a $600 \mathrm{~g}$ silica gel (60 - 200 mesh size) to yield crystals of columbin (eluting solvent: dichloromethane $100 \%$ ).

\section{Single-crystal x-ray diffraction analysis}

The colorless needle-shaped crystal of columbin was subjected to single-crystal X-ray diffraction analysis to determine its structure unambiguously. The solid state experiment was accomplished at $100 \mathrm{~K}$ using $\varphi-\omega$ scan mode for collection of diffraction data on Bruker D8 venture fitted with $\mathrm{Cu} \mathrm{Ka}$ radiation source $(\lambda=$ $1.54178 \AA$ ) and CCD detector (PHOTON 100 diffractometer). Crystal data were reduced using SANIT program [15] while the structure was solved by direct method with the aid of SHELXS86 program [16]. All non-hydrogen atoms were refined anisotropically through full matrix least 
square refinement methods on $\mathrm{F}^{2}$ by using SHELXL-97 program during the structure elucidation [17]. The hydrogen atoms on the parent compound in the constructed structure were placed at calculated positions $(0.95$ - $1.0 \AA)$ with isotropic thermal displacement parameter $U_{\text {iso }}(\mathrm{H})=1.2$ - 1.5 through riding model. ORTEP was used to plot the diagram of molecular structure with $40 \%$ thermal ellipsoid [18]. The significant supramolecular interactions within the crystal lattice, were found with PLATON program [19], while quantitative analysis of inter-molecular interaction was done using the Crystal Explore 3.0 program [20].

\section{Hirshfeld surface analysis}

The number of interactions present in the crystal lattices was determined qualitatively and quantitatively via three-dimensional Hirshfeld surface analysis and two-dimensional fingerprint plots, respectively. The strength of non-covalent interactions was forecasted by using the colorcoding scheme in 3D Hirshfeld surface while twodimensional fingerprint plots was used to find out the contribution of different contacts utilized in crystal packing toward the total interactions.

\section{Assay of anticholinesterase activity}

Inhibition of AChE by columbin was assessed by the method of Ellman et al [21]. The AChE activity was determined in a reaction mixture in a 96-well plates containing $240 \mu \mathrm{L}$ of buffer (50 $\mathrm{mM}$ Tris- $\mathrm{HCl}, \mathrm{pH} 8.0), 20 \mu \mathrm{L}$ of columbin (1 $\mathrm{mg} / \mathrm{mL})$, and $20 \mu \mathrm{L}$ of AChE enzyme (0.28 $\mathrm{U} / \mathrm{mL})$. After incubation for $30 \mathrm{~min}$ at $37^{\circ} \mathrm{C}, 20 \mu \mathrm{L}$ of $10 \mathrm{mM}$ 5,5-dithio-bis(2-nitrobenzoic) acid (DTNB) was added. The AChE activity was determined with a microplate reader from the absorbance changes at $412 \mathrm{~nm}$ over a period of $4 \mathrm{~min}$ at $30 \mathrm{~s}$ intervals. The experiments were done in triplicate with eserine - used as standard. The inhibition $(\mathrm{H})$ of AChE was determined by comparison of rates of reaction of samples relative to blank sample using Eq 1.

$H(\%)=\{(E-S) / E\} 100$

where $E$ is the activity of enzyme without test sample and $S$ is the activity of enzyme with test sample.

\section{Ferrous chelation assay}

The ferrous ion-chelating (FIC) assay was carried out according to the method of Singh and Rajini, [22] with some modifications. Solutions of $2 \mathrm{mM} \mathrm{FeCl} \cdot 4 \mathrm{H}_{2} \mathrm{O}$ and $5 \mathrm{mM}$ ferrozine were diluted 20 times in distilled water. In the assay, 1
$\mathrm{mL}$ of columbin (1 $\mathrm{mg} / \mathrm{mL}$ ) was mixed with $1 \mathrm{~mL}$ $\mathrm{FeCl}_{2} \cdot 4 \mathrm{H}_{2} \mathrm{O}$. After 5 min incubation at $25^{\circ} \mathrm{C}$, the reaction was initiated by the addition $1 \mathrm{~mL}$ of ferrozine. The mixture was shaken vigorously and after a further 10 min incubation period at $25^{\circ} \mathrm{C}$, the absorbance of the solution was measured at $562 \mathrm{~nm}$. The control was prepared as above but the test drug was replaced with $1 \mathrm{~mL}$ of methanol. Ethylenediaminetetraacetic acid (EDTA) was used as positive control. The inhibition (B) of ferrozine- $\mathrm{Fe}^{+2}$ complex formations was calculated as in Eq 2.

$B(\%)=\{(A c-A s) / A c\} 100$

where Ac and As are the absorbance of control and test samples, respectively. The extract concentration providing $50 \%$ inhibition $\left(\mathrm{IC}_{50}\right)$ was calculated by interpolation from linear regression analysis.

\section{Molecular docking studies}

In order to predict the binding mode of columbin as putative acetylcholinesterase inhibitor [], molecular docking studies were carried out with the available protein data bank (PDB) ID:10CE (acetylcholinesterase (E.C. 3.1.1.7) of the enzyme from Tetronarce californica (Pacific electric ray) complexed with an inhibitor MF268 (physostigmine analogue 8-(cis-2,6dimethylmorpholino) octylcarbamoyleseroline) [23]. The builder module in MOE 2015 was used to draw the structures. The compound was energy-minimized, followed by addition of partial charges as per Merck Molecular Force Field (MMFF94). Docking was done using MOE 2015.010 after initial protein preparation. The default rigid docking protocol in MOE Suite was utilized for docking. The resulting poses of the compound was visually inspected to comprehend protein ligand interactions. The interactions were analyzed with PLIP web server (https://projects.biotec.tu-dresden.de/plipweb/plip). All the visuals were recorded using MOE 2015 Suite.

\section{Statistical analysis}

Applicable data were analyzed using GraphPad Prism 6.0, and expressed as mean \pm standard deviation (SD). $P<0.05$ was considered statistically significant.

\section{RESULTS}

\section{Crystal packing}

The packing arrangement of the molecule showed the presence of five different inter- 
molecular interactions dominant in the crystal structure with no intra-molecular interaction. In crystal lattice, asymmetric unit joined with the neighboring molecules via $\mathrm{O} 3-\mathrm{H} 1 \ldots \mathrm{O} 4, \mathrm{C} 12-$ $\mathrm{H} 12 \mathrm{~A} . . . \mathrm{O} 2, \mathrm{C} 13-\mathrm{H} 13 \ldots \mathrm{O} 2, \mathrm{C} 12-\mathrm{H} 12 \mathrm{~A} . . . \mathrm{O} 4$ and C18-H18...O4 inter-molecular hydrogen bonding, and form $R \in(F) R \in(B)$, and $R E$ in $)$ ring motifs. The seven-member ring motifs $R \in(F)$ and $R E(7)$ generated by self-linkage of neighboring molecule through $\mathrm{C} 12-\mathrm{H} 12 \mathrm{~A}$...O4, C18-H18...O4 $\mathrm{C} 12-\mathrm{H} 12 \mathrm{~A} . . \mathrm{O} 2$, C12-H12A...O4, and O3$\mathrm{H} 1$... 04 , interactions respectively. The ring motif $\mathrm{RE(R)}$ was assembled by $\mathrm{C} 12-\mathrm{H} 12 \mathrm{~A}$...O2 and $\mathrm{C} 13-\mathrm{H} 13 . . \mathrm{O} 2$ inter-molecular interactions as shown in Figure 2. The non-covalent interactions O3-H1...O4, C12-H12A...O2, C13-H13...O2, $\mathrm{C} 12-\mathrm{H} 12 \mathrm{~A} \ldots \mathrm{O} 4$ and $\mathrm{C} 18-\mathrm{H} 18 \ldots \mathrm{O} 4$ aligned the molecules in three-dimensional network with donor-acceptor bond distances of 3.183(2) $\AA$,

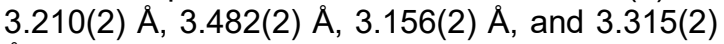
$\AA$, respectively. The crystal lattice of columbin molecules are inter connected with one another through the screw symmetry (Figure 2).

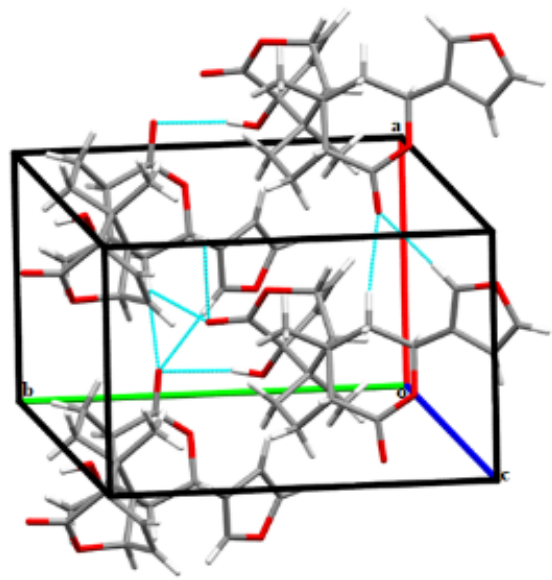

Figure 2: Unit cell diagram showing the packing arrangement of columbin molecules

\section{Hirshfeld surface analysis result}

The relative contributions of $\mathrm{H} \ldots \mathrm{H}, \mathrm{O} \ldots \mathrm{H}, \mathrm{C} \ldots \mathrm{H}$, $\mathrm{O}$... O and $\mathrm{C} \ldots \mathrm{O}$ interactions toward crystal stability were $51.1,38.2 \%, 8.5,0.7$, and $2.2 \%$ respectively over $100 \%$ interaction (Figures 3 and 4).
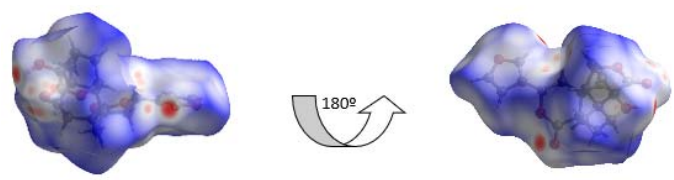

Figure 3: The $\mathrm{d}_{\text {norm }}$ mapped on the Hirshfeld surface for visualizing the intermolecular contacts of columbin
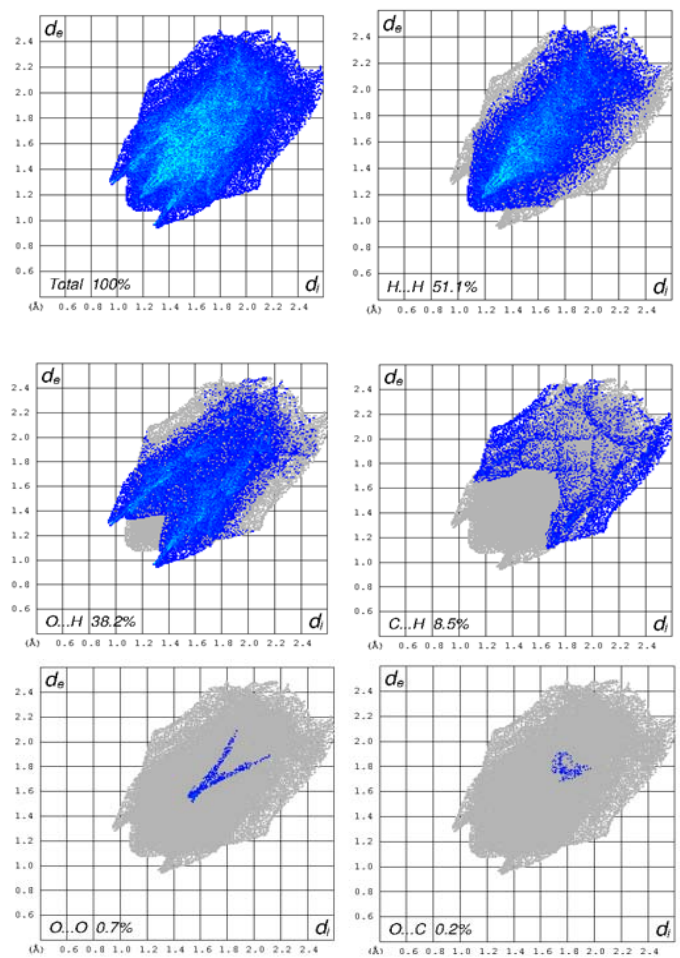

Figure 4: Two-dimensional fingerprint plots indicating the major and minor contributions of inter-molecular interactions in columbin

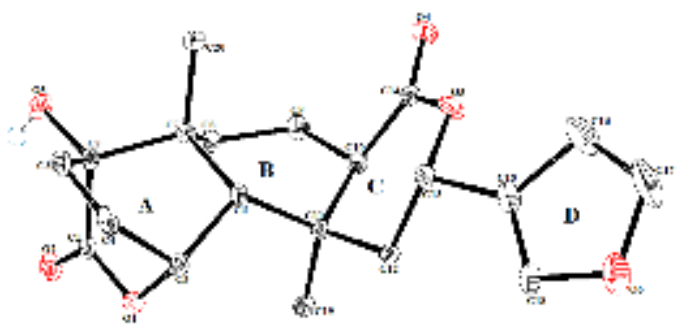

Figure 5: The molecular structure of columbin drawn at $40 \%$ probability level

\section{Acetylcholinesterase inhibitory and metal chelating potential of columbin}

The acetyl cholinesterase inhibitory and metal chelating effects of columbin are as shown in Table 1.

\section{Molecular docking of protein data bank (PDB ID: $10 \mathrm{CE}$ ) complexed with columbin}

The top ranked docked pose of columbin (Figure 6) revealed that there were four hydrophobic interactions of columbin with ASP 72, TRP 84A, Phe 330A and a hydrogen bond with GLU199 (1.77) with an estimated free binding energy $(\Delta \mathrm{G})$, of $-7.1371 \mathrm{kcal} / \mathrm{mol}$. 
Table 1: Acetylcholinesterase and metal chelating effect of columbin

\begin{tabular}{|c|c|c|}
\hline Compound & $\begin{array}{c}\text { AChE } \\
\text { inhibition } \\
\left(I C_{50} \pm S D\right. \\
(\mathrm{mg} / \mathrm{mL}) \\
\end{array}$ & $\begin{array}{c}\text { Fe } 2+\text { chelating } \\
\text { activity } \\
I_{50} \pm S D(\mathrm{mg} / \mathrm{mL})\end{array}$ \\
\hline Columbin & $1.2993 \pm 0.17$ & $1.8131 \pm 0.01$ \\
\hline $\begin{array}{l}\text { Eserine } \\
\text { (standard) }\end{array}$ & $0.5318 \pm 0.34$ & NA \\
\hline $\begin{array}{l}\text { EDTA } \\
\text { (standard) }\end{array}$ & NA & $0.0450 \pm 0.11$ \\
\hline
\end{tabular}

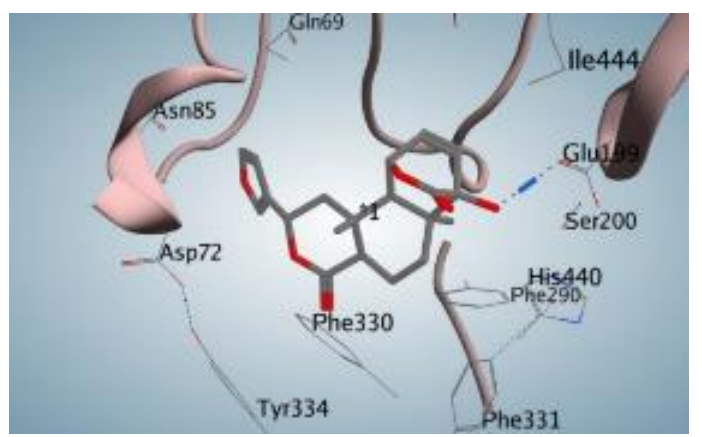

Figure 6: Simulated poses of Columbin. Hydrogen bonds are presented in blue lines. Grey sticks show the ligand while the acetylcholinesterase residues are shown as pink ribbons. The images were generated using MOE 2015.01.08

\section{DISCUSSION}

Single crystal X-ray diffraction is the main source of information on the geometrical structure of molecules and molecular solids, including bond distances (and hence bond orders), bond angles, shapes of coordination, conformations of flexible molecules, as well as intermolecular contacts. It can always distinguish between configurational isomers (e.g. cis and trans), and optical isomers (enantiomers). The single-crystal X-ray diffraction analysis of columbin describes noncentrosymmetric structure consisting of a bicycle ring $A(01 / C 1-C 5 / C 2-C 7)$ fused with sixmembered rings $\mathrm{B}(\mathrm{C} 6-\mathrm{C} 7) / \mathrm{C} 8-\mathrm{C} 11)$ and $\mathrm{C}$ (C10/C11/C12/C13/O5/C14) along C6/C7 and C10/C11 respectively. The solid state chemistry showed a bicyclic ring $A$ with a lactone moiety and an olefinic bond between C3 and C4 (1.326(3) A). Furthermore, the hydroxyl group on the bicyclic ring was found to be equatorially oriented at $\mathrm{C} 2$ with $\mathrm{O} 3 / \mathrm{C} 2 / \mathrm{C} 3 / \mathrm{C} 4$ torsion angle of $176.4(18)^{\circ}$. The bicyclic ring $A(01 / C 1-C 5 / C 2-$ C7) having puckering parameters $Q=0.781(2)$ $\AA, \quad \theta=90.55(15)^{\circ}, \varphi=298.90(14)^{\circ}$ for ring $\mathrm{O} 1 / \mathrm{C} 1-\mathrm{C} 5$, and $\mathrm{Q}=0.823(2) \AA, \theta=91.82(14)^{\circ}, \varphi$ $=2.40(14)^{\circ}$ for ring $\mathrm{C} 2-\mathrm{C} 7$ exhibited boat conformation. Ring $\mathrm{B}(\mathrm{C} 6-\mathrm{C} 7) / \mathrm{C} 8-\mathrm{C} 11)$ was also found to exist in boat conformation as indicated by puckering parameter $Q=0.683(2) \AA, \theta=$ $90.59(17)^{\circ}, \varphi=282.12(17)^{\circ}$ with axially oriented methyl on junction carbon atoms $\mathrm{C} 7$ and $\mathrm{C} 11$ with respect to ring $A$ and ring $C$ respectively (Figure 5). However, another lactone ring $\mathrm{C}$, substituted with pseudo equatorially oriented planer furan ring $(\mathrm{O} / \mathrm{C} 15-\mathrm{C} 18)$ at $\mathrm{C} 13$ adopts half chair conformation. The torsion angle of bridge head carbon atoms C2-C3-C4-C6 was $0.3(2)^{\circ}$ and it showed syn-periplanar geometry of atoms. On the whole, the geometrical parameters of the compound are as follows; crystal size: $0.210 \times 0.090 \times 0.070 \mathrm{~mm}^{3}$, empirical formula $\mathrm{C}_{20} \mathrm{H}_{22} \mathrm{O}_{6}$ and weight of 358.37 . The crystal system is orthorhombic with space group of $P 212121$. The Unit cell dimensions were: $a=7.4951(2) \AA\left(\alpha=90^{\circ}\right), b=11.6451(3) \AA(\beta=$ $\left.90^{\circ}\right), \quad c=19.5882(5) \AA\left(\gamma=90^{\circ}\right)$, Volume $=$ 1709.68(8) $\AA^{3}, Z=4$. The density (calculated) was $1.392 \mathrm{Mg} / \mathrm{m}^{3}$ with absorption coefficient value of $0.851 \mathrm{~mm}^{-1}$ (See supplementary data).

One of the most important approaches for treatment of $A D$ involves the enrichment of acetylcholine level in the brain using acetylcholinesterase (AChE) inhibitors [24]. Columbin, a furanoid diterpenoid isolated from ethyl acetate fraction of $T$. cordifolia stem demonstrated good acetylcholinesterase inhibitory effect with $\mathrm{IC}_{50}$ value of $1.2993 \pm 0.17$ $\mathrm{mg} / \mathrm{mL}$, when compared to the standard eserine with $\mathrm{IC}_{50}$ value of $0.5318 \pm 0.34 \mathrm{mg} / \mathrm{mL}$ (Table 1) which indicates that columbin has the potential to increase the half-life of acetylcholine in the brain thereby improving learning and memory. The AChE inhibitory effect of columbin is in agreement with other related diterpenes such as dihydrotanshinone and cryptotanshinone isolated from Salvia miltiorhiza reported to inhibit AChE in a dose-dependent manner [25]. It was reported also that compounds with aromatic hydrocarbons are more potent AChE inhibitors [26]. This study thus confirms the use of $T$. cordifolia as cognitive enhancer and columbin could serve as a potential drug lead for development of new drugs against Alzheimer's disease.

New molecular modeling tactics driven by rapidly improving computational platforms, have resulted in many success stories of the use of computerassisted drug design in the discovery of new mechanism- or structure-based drugs. For instance, berberine, an isoquinoline alkaloid isolated from the dried rhizome of Rhizoma coptidis showed promising cholinesterase inhibitory potential with mostly hydrophobic interactions with the enzyme [27]. The possible interactions between geissospermine, an indoleindoline alkaloid isolated from Geissospermum vellosii and AChE of the Pacific electric ray have 
been studied with molecular docking, in which case hydrogen bonds, hydrophobic interactions and $p-p$ stacking were reportedly involved in the interactions [28]. Infractopicrin an indole alkaloid isolated from Cortinarius infractus binds preferentially to the oxyanion hole of the AChE enzyme via $p-p$ interactions with the aromatic residues [29]. Molecular modeling studies on columbin was performed in order to investigate its binding mode against Tetronarce californica (Pacific electric ray) acetylcholinesterase. A protein data bank (PDB) was chosen and the compound was docked using the coordinates of the cognate ligand [30]. Four hydrophobic interactions of columbin, including with ASP 72, TRP 84A, Phe 330A and a hydrogen bond with GLU199 were observed. Thus, columbin has the potential to delay the neurodegeneration associated with $A D$ due to its ability to bind to the inhibitor site with moderate energy leading to competitive inhibition of the enzyme AChE. In a study, the binding energies of the US-FDA approved drugs donepezil (Aricept), rivastigmine (Exelon), galantamine (Reminyl) and tacrine (Cognex) were found to be 3.58, -5.61, -7.86 and $-6.95 \mathrm{kcal} / \mathrm{mol}$, respectively [31]. Thus, columbin is quite comparable with existing drugs in term of binding energy.

As the demand for new and more effective drugs for $A D$ treatment continues to grow, pharmacological strategies aimed at lowering brain metal ions and targeting $A \beta /$ metal ion interactions has been proposed and this offers good potential to chelation therapy [32]. Metal ions have been shown to abnormally accumulate in the brain with aging as well as in the course of several neurodegenerative disorders including $\mathrm{AD}$ [33]. Columbin showed good metal chelating potential with $\mathrm{IC}_{50}$ value of $1.8131 \pm 0.01 \mathrm{mg} / \mathrm{mL}$ when compared to standard EDTA with $\mathrm{IC}_{50}$ value of $0.0450 \pm 0.11 \mathrm{mg} / \mathrm{mL}$. Columbin therefore, has the ability to lower brain metal ions which has been linked to several neurodegenerative diseases such as Alzheimer's.

\section{CONCLUSION}

Columbin, a furanoid diterpenoid with an orthorhombic crystal system, has been successfully isolated from ethyl acetate fraction of $T$. cordifolia. It has the potential to improve memory and learning, as well as delay the neurodegenerative process associated with Alzheimer's disease due to its ability to competitively inhibit cholinesterase enzyme. The compound could therefore serve as potential lead for novel drug development for the treatment of Alzheimer's disease.

\section{DECLARATIONS}

\section{Acknowledgement}

The authors would like to acknowledge Third World Academy of Science (TWAS) for funding part of this research and International Centre for Chemical and Biological Sciences (ICCBS), University of Karachi for hosting part of the research activities.

\section{Conflict of interest}

No conflict of interest is associated with this work.

\section{Contribution of authors}

We declare that this work was done by the authors named in this article and all liabilities pertaining to claims relating to the content of this article will be borne by the authors. TOE designed the study, supervised the study and produced the final manuscript. JOO collected, analyzed the data and wrote draft manuscript. ZA and $\mathrm{ZU}$ did the molecular docking work. All authors read and approved the manuscript for publication.

\section{Open Access}

This is an Open Access article that uses a funding model which does not charge readers or their institutions for access and distributed under the terms of the Creative Commons Attribution License (http://creativecommons.org/licenses/by/ 4.0) and the Budapest Open Access Initiative (http://www.budapestopenaccessinitiative.org/rea d), which permit unrestricted use, distribution, and reproduction in any medium, provided the original work is properly credited.

\section{REFERENCES}

1. Lengauer $T$, Rarey $M$. Computational methods for bimolecular docking. Curr Pin Struct Biol 1996; 6: 402406

2. Houghton PJ, Howes MJ. Natural Products and Derivatives affecting neurotransmission relevant to Alzheimer's and Parkinson's disease. Neurosignals 2005; 14: 6-22.

3. Ferreira A, Proença C, Serralheiro, MLM, Araújo MEM. The in vitro screening for acetylcholinesterase inhibition and antioxidant activity of medicinal plants from Portugal. J Ethnopharmacol 2006; 108(1): 31-37.

4. Houghton PJ, Ren Y, Howes MJ. Acetylcholinesterase inhibitors from plants and fungi. Nat Prod Rep 2006; 23: 181-199.

Trop J Pharm Res, February 2021; 20(2): 342 
5. Orhan I, Sener B, Choudhary MI, Khalid A. Acetylcholinesterase and butyrylcholinesterase inhibitory activity of some Turkish medicinal plants. $J$ Ethnopharmacol 2004; 91: 57-60.

6. Ranasinghe S, McManus DP. Structure and function of invertebrate Kunitz serine protease inhibitors. Dev Comp Immunol 2013; 39(3): 219-227.

7. Kitz RJ, Braswell LM, Ginsburg S. On the question: is acetylcholinesterase an allosteric protein? Mol Pharmacol 1970; 6: 108-121.

8. Loizzo MR, Menichini F, Conforti F, Tundis R, Bonesi M, Saab AM, Statti GA, Cindio B, Houghton PJ, Menichini $F$, Frega NG. Chemical analysis, antioxidant, antiinflammatory and anticholinesterase activities of Origanum ehrenbergii Boiss and Origanum syriacum L. essential oils. Food Chem 2009; 117: 174-180.

9. Hodges JR. Alzheimer's centennial legacy: origins, landmarks and the current status of knowledge concerning cognitive aspects. Brain 2006; 129: 2811 2822.

10. Rong $Q$, Xu M, Dong Q, Zhang YL, Li YL, Ye G, Zhao L. In vitro and in vivo bactericidal activity of Tinospora sagittata (Oliv.) Gagnep. var. craveniana (S.Y. Hu) Lo and its main effective component, palmatine, against porcine Helicobacter pylori. BMC Complement Altern Med 2016; 16: 331.

11. Sachdeva H, Sehgal $R$, Kaur S. Tinospora cordifolia as a protective and immunomodulatory agent in combination with cisplatin against murine visceral leishmaniasis. Exp Parasitol 2014; 137: 53-65.

12. Singh $B$, Sharma $P$, Kumar $A$, Chadha $P, \operatorname{Kaur} R$, Kaur $A$. Antioxidant and in vivo genoprotective effects of phenolic compounds identified from an endophytic Cladosporium velox and their relationship with its host plant Tinospora cordifolia. J Ethnopharmacol 2016; 194: 450-456.

13. Singh SS, Pandey SS, Srivastava S, Gupta VS, Patro B, Ghosh AC. Chemistry and medicinal properties of Tinospora cordifolia (Guduchi). Ind J Pharmacol 2003; 35: 83-91.

14. Mishra R, Kaur G. Tinospora cordifolia induces differentiation and senescence pathways in neuroblastoma cells. Mol Neurobiol 2015; 52(1): 719733.

15. Saint S. For Windows NT (version 6.02 a). Bruker Analytical X-ray Instruments Inc., Madison, Wisconsin, USA. 1998

16. Sheldrik G. Program for crystal structure determination. SHELXS 86. 1986.

17. Sheldrick G. Program for the refinement of crystal structures. SHELXL97. 1997.

18. Farrugia LJ. ORTEP-3 for Windows-a version of ORTEP-III with a Graphical User Interface (GUI). J Appl Crystallogr 1997; 30(5-1): 565-565.
19. Spek AL. Single-crystal structure validation with the program PLATON. J. Appl Crystallogr 2003; 36(1): 7-13.

20. Wolff S, Grimwood D, McKinnon J, Turner M, Jayatilaka D, Spackman M. CrystalExplorer 3.0, University of Western Australia, Perth. 2012.

21. Ellman GL, Courtney KD, Andres V, Featherstone RM. A new and rapid colorimetric determination of acetylcholinesterase activity. Biochem Pharmacol 1961; 7: 88-95.

22. Singh N, Rajini PS. Free radical scavenging activity of an aqueous extract of potato peel. Food Chem 2004; 85(4): 611-616.

23. Bartolucci C, Perola E, Cellai L, Brufani M, Lamba D. "Back Door" Opening Implied by the Crystal Structure of a Carbamoylated Acetylcholinesterase. Biochem 1999; 38: 5714-5719.

24. Norberge A, Darreh-Shori T, Svenson A, Quan Z. AChE and BuChE activities in CSF of mild $A D$ patients following 12 months of rivastigmine treatment. J Neurol Sci 187 (suppl): 2001; PQ 144.

25. Yuhao R, Peter JH, Robert CH, Melanie-Jayne RH. Novel Diterpenoid Acetylcholinesterase Inhibitors from Salvia miltiorhiza. Planta Med 2004; 70(3): 201-204.

26. Korpela M, Tahti H. The effect of selected organic solvents on intact human red cell membrane acetylcholinesterase in vitro. Toxicol Appl Pharmacol 1986; 85: 257-262.

27. Ji HF, Shen L. Molecular basis of inhibitory activities of berberine against pathogenic enzymes in Alzheimer's disease. The Scientific World Journal Article 2012; ID 823201, 1-4

28. Araújo JQ, Lima JA, Angelo da Cunha Pinto, Ricardo Bicca de Alencastro, Albuquerque MG. Docking of the alkaloid geissospermine into acetylcholinesterase: $A$ natural scaffold targeting the treatment of Alzheimer's disease. J Mol Mod 2011; 17: 1401-1412.

29. Geissler T, Brandt W, Porzel A, Schlenzig D, Kehlen A, Wessjohann L, Arnold N. Acetylcholinesterase inhibitors from the toadstool Cortinarius infractus. Bioorg Med Chem 2010; 18: 2173-2177.

30. Fukuto TR. Mechanism of action of organophosphorus and carbamate insecticides. In Environmental Health Perspectives. 1990; 245-254 https://doi.org/10.1289/ehp.9087245

31. Jagmohan S, Ramanathan K, Rao S. Identification of Potential Inhibitors against Acetylcholinesterase Associated with Alzheimer's Diseases: A Molecular Docking Approach. J Comput Method Mol Design 2011; (1): 44-51.

32. Valko $M$, Morris $H$, Cronin MT. Metals, toxicity and oxidative stress. Curr Med Chem 2005; 12: 1161-1208.

33. Campbell A, Smith MA, Sayre LM, Bondy SC, Perry G. Mechanisms by which metals promote events connected to neurodegenerative diseases. Brain Res Bull 2001; 55: 125-132. 